\title{
Effect of Size and Surface Roughness of Cylindrical Weirs on Over Flow Characteristics
}

\author{
Khalil I. Othman Tahssen A. Chilmeran Ibrahim A. I. Al-Hafith
}

Dams \& Water Resource Research Center / Mosul University

\begin{abstract}
:
weirs are the most commonly used device in channels for flow measurement and flow regulation due to its simplicity. Conventional rectangular, triangular and trapezoidal weirs are among the most common oldest types of weirs, progress ogee crest weir and cylindrical weirs are started to use in hydraulic engineering. The advantages of the circular weir shape are the stable overflow pattern compared to sharp-crested weirs, the ease to pass floating debris and the simplicity of design. The concern of this paper is to study the effect of size and surface roughness of cylindrical weirs on discharge coefficients $(\mathbf{C d})$ under different flow conditions.

The work was conducted in experimental flume by using three sizes of cylinders and three types of surface roughness. The obtained results show that $\mathrm{Cd}$ values will increase with increasing flow rate as well as with decreasing in cylinder diameter; an increase in surface roughness of weir can makes great reduction in $C d$ value. $T h e ~ h / R$ effect on Cd values increase with increase in cylinder diameter. An empirical relation was obtained to estimate the coefficient of discharge $\mathrm{Cd}$ under different size and surface roughness of cylindrical weirs.
\end{abstract}

Key Words: Cylindrical weir, Discharge coefficient, Experimental study, surface roughness

$$
\begin{aligned}
& \text { تأثير حجم وخشونة سطح السدود الغاطسة الاسطوانية على المران }
\end{aligned}
$$

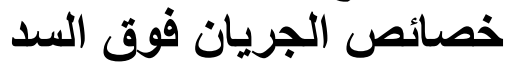

$$
\begin{aligned}
& \text { خليل ابراهيم عثمان تحسين علي جلميران } \\
& \text { مركز بحوث السدود و الموارد المائية / جامعة الموصل }
\end{aligned}
$$

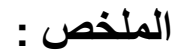

$$
\begin{aligned}
& \text { تعتبر السدود الغاطسة من اكثر الادوات استخداما في قياس التصريف وتنظيم الجناس الجريان بسبب بساطتها. }
\end{aligned}
$$

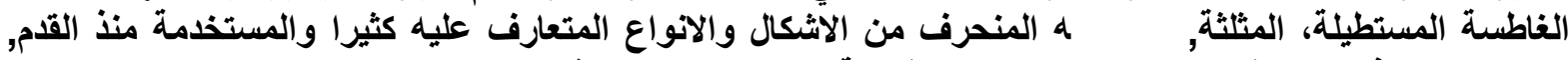

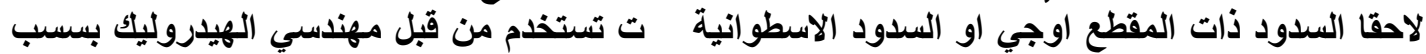

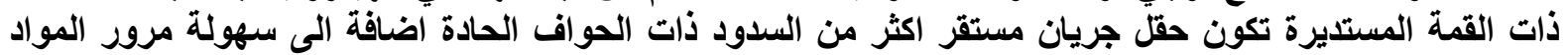

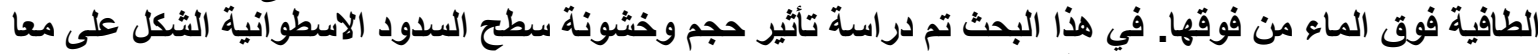

$$
\begin{aligned}
& \text { التصريف عند ظروف جريان مختلفة. } \\
& \text { تجارب مختبرية باستخدام ثلاث اسطوانات باقطار مختلفة ولكل اسطوانة تم استخدام ثُلاث }
\end{aligned}
$$

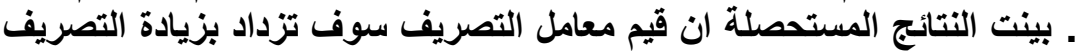

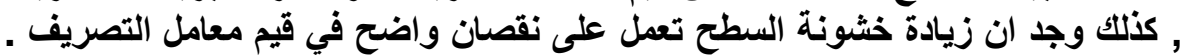

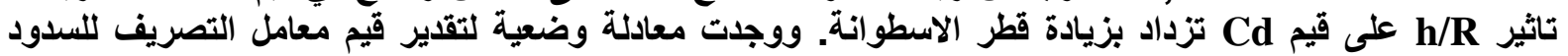

$$
\begin{aligned}
& \text { نية الشكل تحت ظروف جريان مختلفة. }
\end{aligned}
$$

Received : 6- 4- 2009

Excepted : 4 - 4 - 2010 


\section{Introduction:}

In the fields of hydraulics, environment, irrigation, and chemical engineering, weirs are most widely used as flow measuring and flow control devices. Conventional rectangular, triangular, and trapezoidal weirs are among the oldest weirs. Semicircular weir is a new type of construction developed in 1990's. It has many advantages compared with other types of weirs. Such as; stable overflow pattern compared to sharp-crested weirs, the ease to pass floating debris, the simplicity of design compared to ogee crest design, and the associated lower cost. Also it has larger discharge capacity (for identical upstream head) than broadcrested weirs and sharp-crested weirs [1].

It is very important to investigate the behaviours of the flow over the weir. A large number of studies have been devoted to the flow over the weirs Bazin [see Ref. 2] was the first to study the flow characteristics of trapezoidal profile weirs systematically. $\mathrm{He}$ conducted series of experiments on these types of weirs with both upstream and downstream side slopes. The discharge coefficient was determined for free flow conditions using different discharge values.

Kandaswamy and Rouse [3] have done experimental investigations on rectangular weirs. U.S.B.R [4] studies various profiles of Ogee weirs with inclined upstream and downstream faces, in order to improve the discharge coefficient of the weir. Aichel [see Ref.5] expressed the discharge coefficient of the round crested skew weir to the discharge coefficient of a normal weir.

Ganapathy et. al. [6] established design curves for the discharge coefficient and the head with the skew angle as the third parameter. Mohapatra [7] carried out an investigation to obtain the discharge coefficient for oblique terminal weirs. Muralidhar [8] conducted experiments on broad-crested skew weirs.

Sarginson [9] investigations on circular weirs showed that the discharge coefficient $\mathrm{Cd}$ was close to and usually larger than unity, and $\mathrm{Cd}$ was primarily a function of the ratio of upstream head to crest radius (HW/R). Ramamurthy et. al. [10] studied the flow characteristics of rectangular broad-crested weirs with vertical upstream walls under free flow and submerged flow conditions. The study was focused on examining the effects of rounding of the upstream top corner of the weir on flow surface profile, bed pressure profile, and discharge characteristics. Ramamurthy and Vo.[11] tried to improve the discharge coefficient by providing different upstream and downstream slopes for circular-crested weirs Keshava and Shesha [12],[13] presented a general numerical optimization procedure to obtain the proportionality range for any sharp-crested weir to develop any type of head-discharge relationship. Keshava and Shesha [14] presented a general algebraic optimization procedure to obtain the linear characteristics for an inverted semicircular weir. Chanson and Montes [1] describe experimentally the flow over circular weir under different flow conditions that the overflow is characterised by nape adherence on the downstream cylinder face and overflow properties are significantly affected by the upstream flow conditions.

Liu et. al. [15] investigate numerically and experimentally the flow over semicircular weir. This review demonstrates that most of the experimental works have been performed towards the understanding of the flow characteristics over the weirs and also the determination of the coefficients of discharge under different flow conditions, none of these studies has search about the effect of surface roughness of the weir on flow properties.

In this paper the flow over a cylindrical weir is investigated, in order to find out the effect of diameter and surface roughness of the cylinder weir on discharge coefficient and flow characteristics over the weir. 


\section{Experimental Setup and Procedure:}

The experiments were conducted in a horizontal rectangular flatbed flume $10.0 \mathrm{~m}$ long, $30 \mathrm{~cm}$ wide and $45 \mathrm{~cm}$ high. The flume has glass-sided walls and smooth aluminium flatbed. A sharp-crested weir $35 \mathrm{~cm}$ height and $30 \mathrm{~cm}$ width was fixed at $2 \mathrm{~m}$ downstream from the flume inlet, the weir calibrated and used as a measuring device for the entering flow see fig. 1 . The flume was provided with various screens upstream and downstream of the sharp-crested weir in order to improve the approach flow. Three cylindrical size with a diameters $(\mathrm{D}=$ $7.62 \mathrm{~cm}, 10.16 \mathrm{~cm}$, and $15.24 \mathrm{~cm}$ ) were used as a cylindrical weir, and for each diameter of cylinder three types of surface roughness were used, the first set was smooth PVC and second coated with a uniform sand $\mathrm{D}_{50}=1.2 \mathrm{~mm}\left(\mathrm{D}_{50}=\right.$ is the sieve diameter in which $50 \%$ of material are finer) while the third covered by gravel of $\mathrm{D}_{50}=2.5 \mathrm{~mm}$.Nine cylinders where used to conduct the experimental work. In each run the selected cylinder was inserted along the width of the flume at a distance $3.5 \mathrm{~m}$ downstream sharp weir, then the pump started at desired flow rate and after the flow uniformity was verified the water surface level upstream and above the cylindrical weir where measured using point gauge. The rate of the supplied flow at each experiment was controlled by electrical board of the flume pump and measured by the sharp-crested weir. In all experiments the downstream face of the cylinders was not ventilated. Fig. 2 shows the water profile above the wire for cylinder type 3 (Diameter 15.24 $\mathrm{cm}$ Coated with gravel $\mathrm{D}_{50}=2.5 \mathrm{~mm}$ ). For each kind of cylinder a series of tests under different flow rates are conducted. A total of 45 runs were conducted at the experimental work.

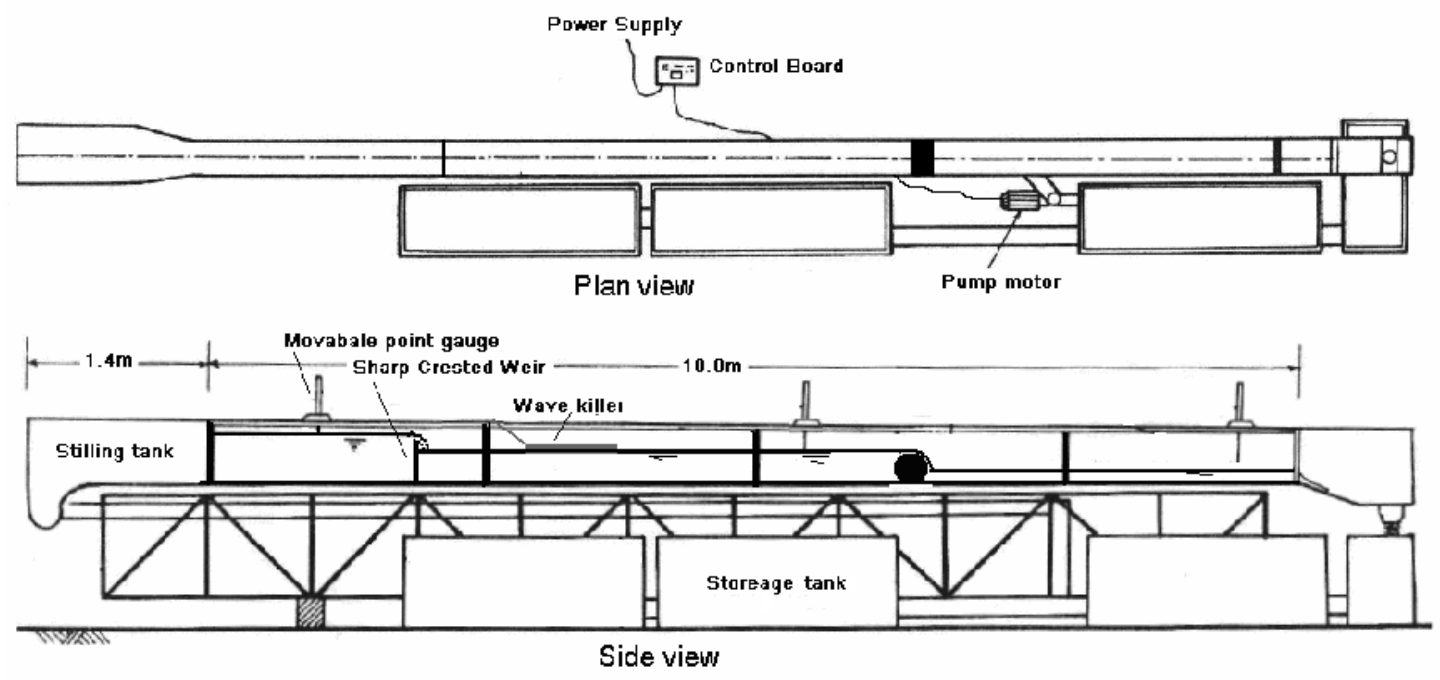

Fig. 1: Experimental layout.
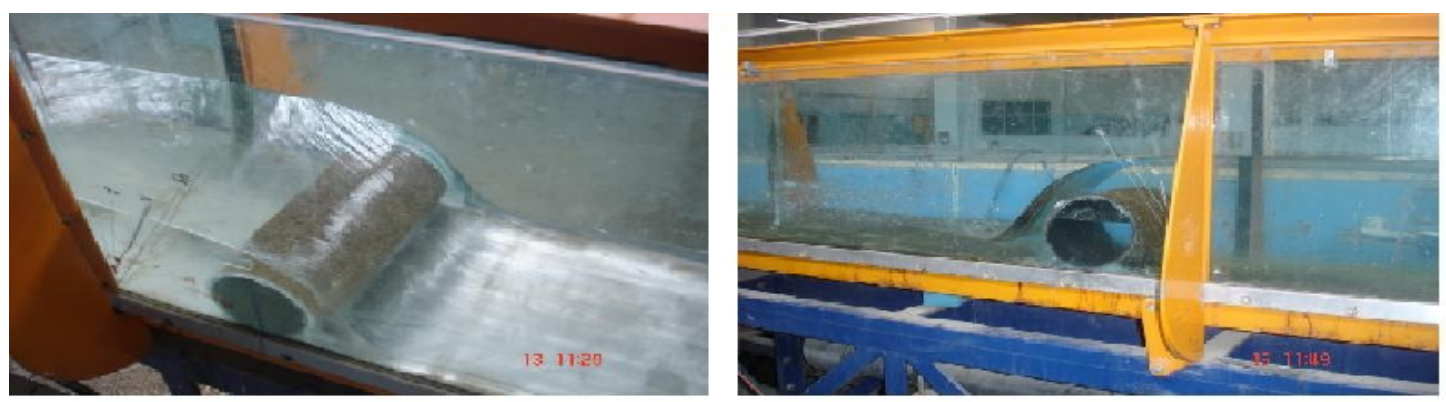

Fig.2: The flow over the Weir for Cylinder type 3 (Diameter $15.24 \mathrm{~cm}$ Coated with gravel $\mathrm{D} 50=2.5 \mathrm{~mm}$ ). 


\section{Results and Discussion:}

For ideal fluid flow the maximum discharge per unit width (qw ) at a weir crest equals:

$$
\mathrm{qW}=\frac{2}{3} \sqrt{2 g}(\mathrm{H})^{3 / 2}
$$

Where $\mathrm{g}\left(\mathrm{m}^{2} / \mathrm{sec}\right)$ is the gravity acceleration and $\mathrm{H}(\mathrm{m})$ is the upstream total head above the weir crest. Equation (1) derives from the Bernoulli equation assuming hydrostatic pressure distribution at the crest and a uniform velocity distribution for a rectangular channel [16]. In practice the observed discharge differs from equation (1) because the pressure distribution on the crest is not hydrostatic and the velocity distribution is not uniform [16]. Usually the flow rate is expressed as:

$$
\mathrm{qW}=\mathrm{Cd} \frac{2}{3} \sqrt{2 g}(\mathrm{H})^{3 / 2}
$$

Where $\mathrm{Cd}$ is the discharge coefficient. It equals unity for an ideal flow condition. By using the Eq. 2 and data obtained from the experimental work the values of $\mathrm{Cd}$ for each weir under different rates of flow has been calculated in order to explore the effect of size and surface roughness of cylindrical weir on the value of the $\mathrm{Cd}$.

\section{Effect of Discharge, Cylinder Diameter and surface Roughness on Cd :}

To illustrate the changes in $\mathrm{Cd}$ values with the discharge .The values of $\mathrm{Cd}$ are plotted against the unit discharge for different cylinders under the same surface roughness as shown in Figs. 3, 4 and 5. It's evident from these figures that there is an increase in Cd values with increasing in the rate of the flow. The figures denote also, that the Cd values vary inversely with the cylinder diameter. To find out the effect of cylinder surface roughness on $\mathrm{Cd}$, the values of $\mathrm{Cd}$ are plotted as function of discharge for the same size of the cylinder but under different surface roughness as shown in Figs. 6, 7, and 8.

These figures show that $\mathrm{Cd}$ values decreases with the increase in surface roughness and this attributed to the fact that an increasing in roughness of cylinder will lead to increase in the head of the water, and according to Eq.1: if the discharge has fixed at constant value, any increase in $\mathrm{H}$ value will faced by reduction in $\mathrm{Cd}$ value.

To clarify numerically the effect of discharge, cylinder size and surface roughness on $\mathrm{Cd}$ value, the percentage of changes in $\mathrm{Cd}$ values with the percentage increase in discharge, cylinder diameter, and surface roughness are calculated as shown in Tables 1, 2, and 3 respectively 


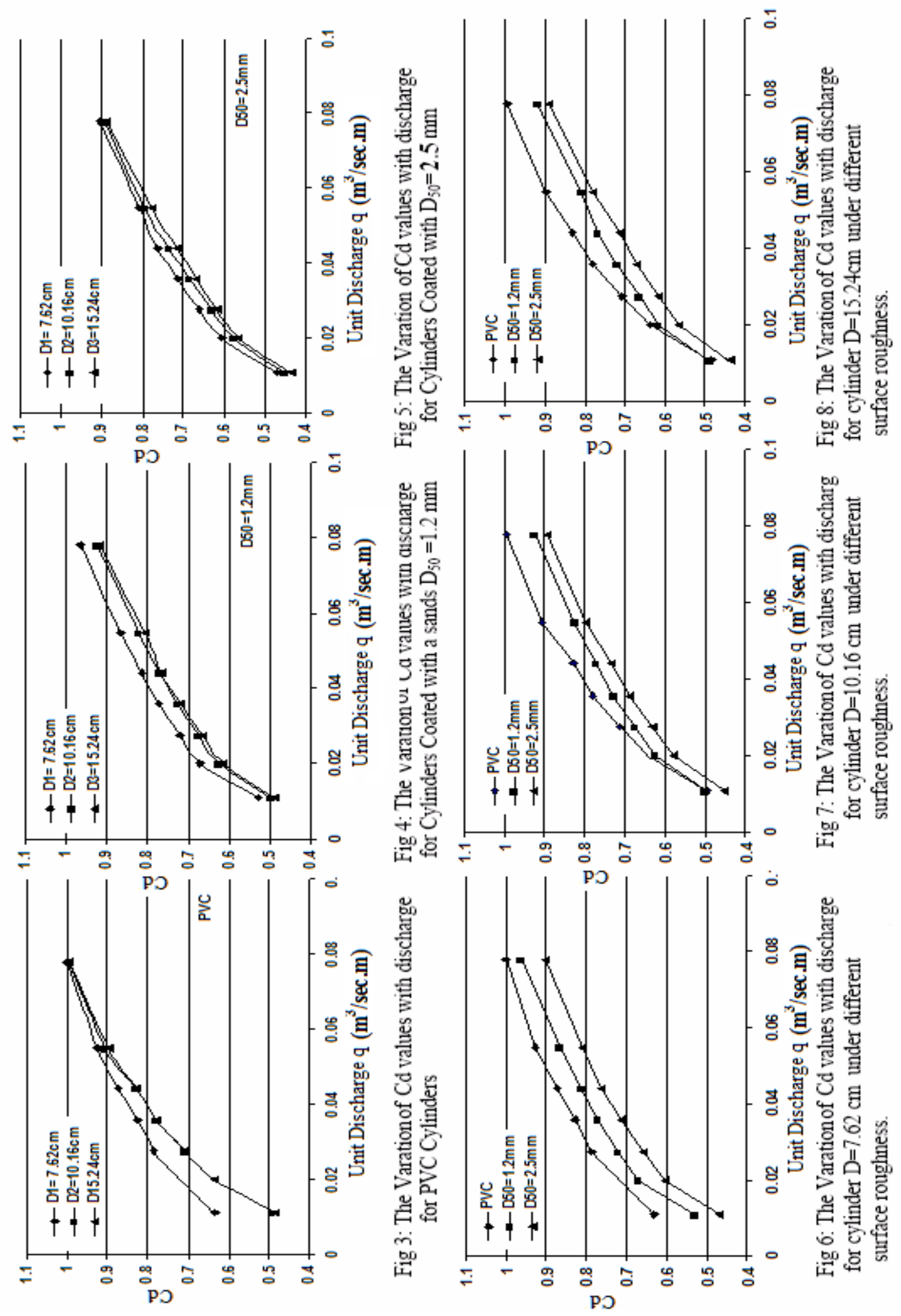


Table 1 show that an increase in discharge of $618.2 \%$ led to increase in Cd value 65.9, $110.7,112 \%$ for weirs diameters $7.62 \mathrm{~cm}, 10.16$ and $15.24 \mathrm{~cm}$, respectively for smooth surface weirs. While for cylinders coated by sand of $\mathrm{D}_{50}=1.2 \mathrm{~mm}$ the rate of the increase in $\mathrm{Cd}$ was $81.7 \%, 85.4 \%, 87.58 \%$ and for cylinders coated by gravel $\mathrm{D}_{50}=2.5 \mathrm{~mm}$ the rate of increase in Cd was $92 \%, 97 \%$,

Table 1: The percentage of increase in $\mathrm{Cd}$ with percentage of increase in discharge.

\begin{tabular}{|c|c|c|c|c|c|c|c|c|}
\hline \multirow[b]{2}{*}{$\begin{array}{l}\text { Cylinder } \\
\text { Diameter }\end{array}$} & \multirow[b]{2}{*}{$\begin{array}{c}\mathbf{q} \cdot \\
\mathbf{m}^{3} / \mathbf{s e c} . \mathbf{m}\end{array}$} & \multirow[b]{2}{*}{$\begin{array}{c}\% \\
\text { increase } \\
\text { in } \mathbf{q}\end{array}$} & \multicolumn{2}{|c|}{ Smooth ( PVC) } & \multicolumn{2}{|c|}{$\begin{array}{c}\text { Coated } \\
D_{50}=1.2 \mathrm{~mm}\end{array}$} & \multicolumn{2}{|c|}{$\begin{array}{c}\text { Coated } \\
D_{50}=2.5 \mathrm{~mm}\end{array}$} \\
\hline & & & Cd & $\begin{array}{c}\% \\
\text { increase } \\
\text { in Cd } \\
\text { values }\end{array}$ & Cd & $\begin{array}{c}\% \\
\text { increase } \\
\text { in Cd } \\
\text { values }\end{array}$ & Cd & $\begin{array}{c}\% \\
\text { increase } \\
\text { in Cd } \\
\text { values }\end{array}$ \\
\hline \multirow{8}{*}{$\begin{array}{c}\mathrm{D} 1=7.62 \\
\mathrm{~cm}\end{array}$} & & & Cd1-1 & & Cd1-2 & & Cd1-3 & \\
\hline & 0.011 & $\mathbf{0}$ & 0.633 & & 0.530 & & 0.470 & \\
\hline & 0.020 & 84.621 & --.-- & ------. & 0.672 & 26.834 & 0.604 & 28.493 \\
\hline & 0.027 & 153.076 & 0.786 & 24.301 & 0.721 & 36.052 & 0.660 & 40.267 \\
\hline & 0.036 & 229.800 & $\mathbf{0 . 8 2 7}$ & 30.760 & 0.772 & 45.615 & 0.713 & 51.652 \\
\hline & 0.044 & 306.678 & 0.873 & 38.031 & 0.812 & 53.181 & 0.763 & 62.311 \\
\hline & 0.055 & 404.953 & 0.927 & 46.552 & 0.864 & 63.009 & 0.808 & 71.875 \\
\hline & 0.078 & 618.209 & 1.000 & 65.901 & 0.963 & 81.694 & 0.903 & 91.936 \\
\hline \multirow{8}{*}{$\begin{array}{c}\mathrm{D} 2=10.16 \\
\mathrm{~cm}\end{array}$} & & & Cd2-1 & & Cd2-2 & & Cd2-3 & \\
\hline & 0.011 & & 0.494 & & 0.499 & & 0.453 & \\
\hline & 0.020 & 84.621 & ------- & & 0.626 & 25.521 & 0.578 & 27.606 \\
\hline & 0.027 & 153.076 & 0.711 & 44.129 & 0.676 & 35.456 & 0.630 & 39.265 \\
\hline & 0.036 & 229.800 & 0.780 & 58.034 & 0.728 & 45.982 & 0.687 & 51.650 \\
\hline & 0.044 & 306.678 & 0.829 & 67.978 & 0.771 & 54.632 & 0.735 & 62.309 \\
\hline & 0.055 & 404.953 & 0.906 & 83.549 & 0.824 & 65.142 & 0.797 & 76.133 \\
\hline & 0.078 & 618.209 & 0.993 & 110.766 & 0.925 & 85.390 & 0.893 & 97.159 \\
\hline \multirow{8}{*}{$\begin{array}{c}\mathrm{D3}=15.24 \\
\mathrm{~cm}\end{array}$} & & & Cd3-1 & & Cd3-2 & & Cd3-3 & \\
\hline & 0.011 & 0.000 & 0.485 & & 0.489 & & 0.436 & \\
\hline & 0.020 & 84.621 & 0.636 & 31.073 & 0.616 & 26.085 & 0.566 & 29.705 \\
\hline & 0.027 & 153.076 & 0.709 & 46.089 & 0.665 & 35.964 & 0.618 & 41.556 \\
\hline & 0.036 & 229.800 & 0.779 & 60.664 & 0.721 & 47.420 & 0.671 & 53.727 \\
\hline & 0.044 & 306.678 & 0.829 & 70.854 & 0.766 & 56.649 & 0.715 & 63.843 \\
\hline & 0.055 & 404.953 & 0.898 & 85.028 & 0.808 & 65.358 & 0.779 & 78.528 \\
\hline & 0.078 & 618.209 & 0.993 & 112.617 & 0.917 & 87.587 & 0.888 & 103.629 \\
\hline
\end{tabular}

Table 2: Shows the rate of decrease in Cd value due to increase in cylinder diameter. Generally, it seems that an increase in weir diameter from $7.62 \mathrm{~cm}$ to $10.16 \mathrm{~cm}$ ( $33 \%$ increase) make a reduction in $\mathrm{Cd}$ value about $5.3 \%$ While an increase in weir diameter from $7.62 \mathrm{~cm}$ to $15.24 \mathrm{~cm}(100 \%$ increase) reduce $\mathrm{Cd}$ values around $6.6 \%$.

$103 \%$ 
Table 2: The percentage of decrease in $\mathrm{Cd}$ values with the increase in the Cylinder diameter

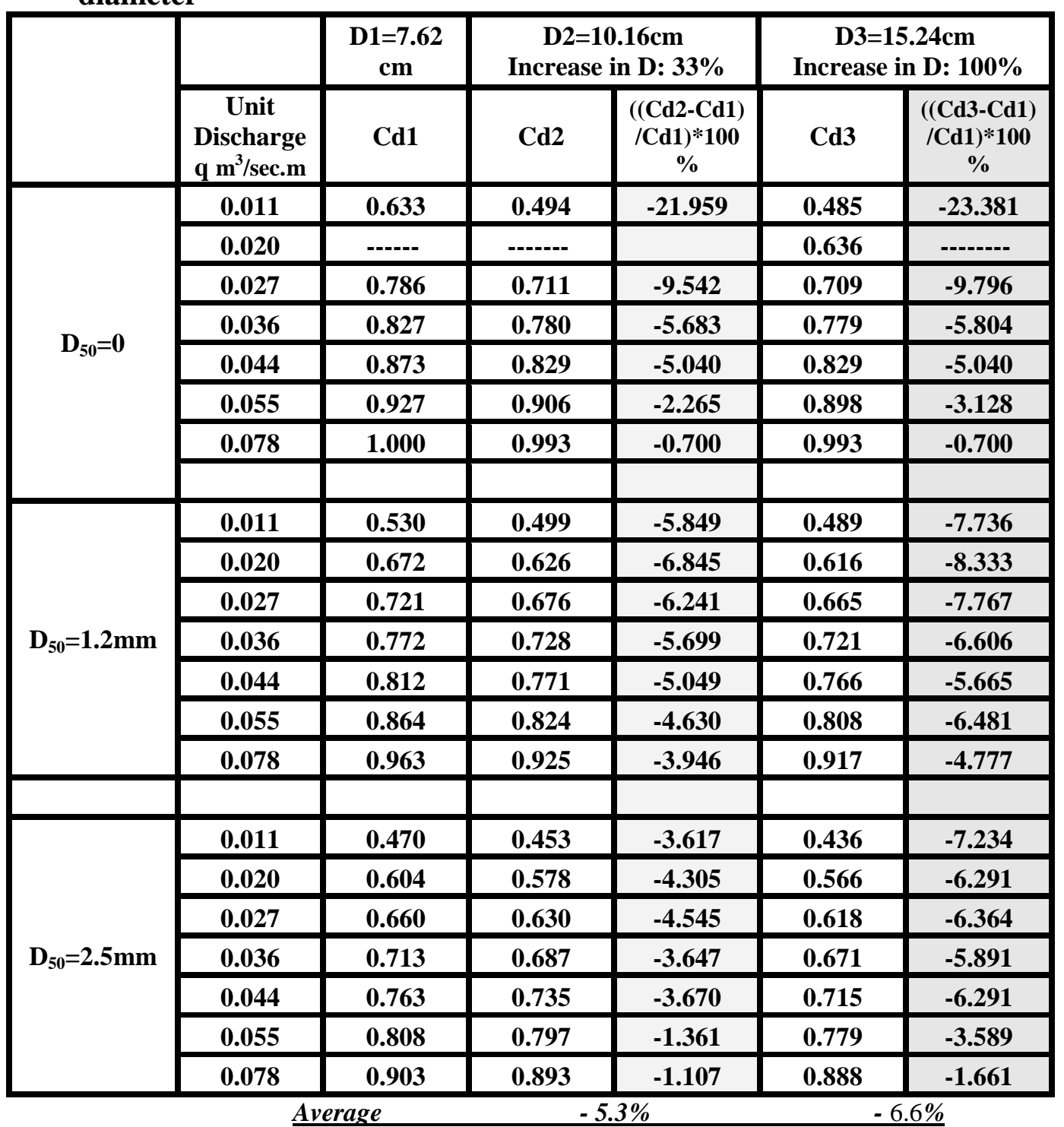

Table 3 shows that for the same cylinder and under equal flow rate an increase in surface roughness of the weir from $\mathrm{D}_{50}=0 \mathrm{~mm}(\mathrm{PVC})$ to $\mathrm{D}_{50}=1.2 \mathrm{~mm}$ makes a reduction in Cd value around $6.5 \%$ ( as an average value), while an increase from $\mathrm{D}_{50}=0 \mathrm{~mm}$ to $2.5 \mathrm{~mm}$ makes a reduction about $13 \%$. Generally this means that an increase in surface roughness of weir make a reduction in $\mathrm{Cd}$ values 
Table 3: The percentage of decrease in $\mathrm{Cd}$ values with the increase in Cylinder roughness

\begin{tabular}{|c|c|c|c|c|c|c|}
\hline \multirow[b]{2}{*}{$\begin{array}{l}\text { Cylinder } \\
\text { Diameter }\end{array}$} & \multirow[b]{2}{*}{ 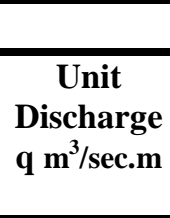 } & \multirow{2}{*}{$\frac{\text { PVC }}{\text { Cd1 }}$} & \multicolumn{2}{|c|}{ Coated $D_{50}=1.2 \mathrm{~mm}$} & \multicolumn{2}{|c|}{ Coated $D_{50}=2.5 \mathrm{~mm}$} \\
\hline & & & Cd2 & $\begin{array}{c}((\mathrm{Cd} 2- \\
\text { Cd1 }) \\
/ \mathrm{Cd1}) * 10 \\
0 \%\end{array}$ & Cd3 & $\begin{array}{c}((\mathrm{Cd} 3- \\
\mathrm{Cd1}) \\
/ \mathrm{Cd1}) * 100 \\
\%\end{array}$ \\
\hline \multirow{8}{*}{$D 1=7.62 \mathrm{~cm}$} & & Cd1-1 & Cd1-2 & & Cd1-3 & \\
\hline & 0.011 & 0.633 & 0.530 & -16.272 & 0.470 & -25.750 \\
\hline & 0.020 & 0.000 & 0.672 & --.---- & 0.604 & -------- \\
\hline & 0.027 & 0.786 & 0.721 & -8.270 & 0.659 & -16.158 \\
\hline & 0.036 & 0.828 & 0.772 & -6.763 & 0.713 & -13.889 \\
\hline & 0.044 & 0.873 & 0.812 & -6.987 & 0.763 & -12.600 \\
\hline & 0.055 & 0.927 & 0.864 & -6.796 & 0.808 & -12.837 \\
\hline & 0.078 & 1.000 & 0.963 & -3.700 & 0.902 & -9.800 \\
\hline & & & & & & \\
\hline \multirow{8}{*}{$\begin{array}{c}\mathrm{D} 2=\underset{\mathrm{m}}{10.16 \mathrm{c}} \\
\mathrm{m}\end{array}$} & & Cd2-1 & Cd2-2 & & Cd2-3 & \\
\hline & 0.011 & 0.494 & 0.499 & 1.012 & 0.453 & -8.300 \\
\hline & 0.020 & 0.000 & 0.626 & ---------- & 0.578 & --------- \\
\hline & $\mathbf{0 . 0 2 7}$ & 0.711 & 0.675 & -5.063 & $\mathbf{0 . 6 3 0}$ & -11.392 \\
\hline & 0.036 & 0.780 & 0.728 & -6.667 & 0.687 & -11.923 \\
\hline & 0.044 & 0.829 & 0.771 & -6.996 & 0.735 & -11.339 \\
\hline & 0.055 & 0.906 & 0.824 & -9.051 & 0.797 & -12.031 \\
\hline & 0.078 & 0.993 & 0.925 & -6.848 & 0.893 & -10.070 \\
\hline & & & & & & \\
\hline \multirow{9}{*}{$\begin{array}{c}\mathrm{D} 3=15.24 \mathrm{c} \\
\mathrm{m}\end{array}$} & & Cd3-1 & Cd3-2 & & Cd3-3 & \\
\hline & 0.011 & 0.485 & 0.489 & 0.825 & 0.436 & -10.103 \\
\hline & 0.020 & 0.636 & 0.617 & -2.987 & 0.566 & -11.006 \\
\hline & 0.027 & 0.709 & 0.665 & -6.206 & 0.617 & -12.976 \\
\hline & 0.036 & 0.779 & 0.721 & -7.445 & 0.671 & -13.864 \\
\hline & 0.044 & 0.829 & 0.766 & -7.600 & 0.715 & -13.752 \\
\hline & 0.055 & 0.898 & 0.808 & -10.022 & 0.779 & -13.252 \\
\hline & 0.078 & 0.993 & 0.917 & -7.654 & 0.889 & -10.473 \\
\hline & & Average & & $-6.5 \%$ & & $-13 \%$ \\
\hline
\end{tabular}

\section{Variation of Cd with $(\mathbf{h} / \mathbf{R})$ :}

The dimensional analysis for the variables affecting Cd value of weirs [16] shows that the value $(\mathrm{P} / \mathrm{h})$ (Where $\mathrm{P}$ height of the weir, $\mathrm{h}$ is head of the water on the weir), has a greatest influence on $\mathrm{Cd}$ value, in this research the value of $\mathrm{R}(\mathrm{R}=$ radius of the cylinder) was used instead of $\mathrm{P}$ value in order to see the effect of $\mathrm{h} / \mathrm{R}$ on $\mathrm{Cd}$ values of cylindrical weirs. The calculated values of $\mathrm{h} / \mathrm{R}$ are plotted against the $\mathrm{Cd}$ values for each cylinder and for each surface roughness's as shown in Figs 9,10 and 11. The figures shows that $\mathrm{Cd}$ value increase with increasing in $\mathrm{h} / \mathrm{R}$ values for all the cases. Also it's evident from these figures that the 
gradient of the curve fit the points are decrease with increase in cylinder diameter, this means that the effect of $\mathrm{h} / \mathrm{R}$ on $\mathrm{Cd}$ values will increase with increase in cylinder diameter.

The data obtained from the experimental work are used to obtain general empirical formula to calculate the discharge coefficients of circular crested weirs under different surface roughness. The nonlinear regreation analyses are used for this purpose. The obtained equation was in the following form.

$$
C d=0.51\left(\frac{h}{R}\right)^{0.48}+0.57\left(\frac{D}{D_{50}}\right)^{0.21} \ldots \ldots \ldots \mathrm{R}^{2}=0.90
$$

\section{Effect of cylinder diameter and surface roughness on head of water above the weir:}

In order to find the rate of changes in head of water above the cylindrical weir under different conditions the values of $h$ are plotted against the rate of the flow for each cylinder and for each surface roughness as shown in Figs 12, 13, and 14. From principle of continuity equation, for constant width channels the depth of flow increase with increase in the discharge. Figs 12, 13, and 14 clearly show this point, as well, for the same discharge the head of the water increases with increase in cylinder diameter, Fig. 15 clarify this point more clearly. Generally an increase in cylinder diameter from $7.62 \mathrm{~cm}$ to $15.24 \mathrm{~cm}$ leads to increase $\mathrm{h}$ value around $15 \%$. This means that under the same rate of the flow the large cylinder make high level pond than small one.

To explain the effect of surface roughness on water head the values of $h$ are plotted against discharge for different roughness and for each size of cylinder as shown in Fig 16, for cylinder size $D=7.62 \mathrm{~cm}$ as an example, its clear from the figure that there is an increases in $h$ values with increase in roughness of the weir surface and this attributed to restricting action of surface roughness to the following flow. To expose the rate of effect of surface roughness on head of water behind the wire the percentage of increase in $h$ values are calculate for each cylinder as shown in table 4.

Table 4 shows that the effect of increase in surface roughness on $\mathrm{h}$ values are large in small cylinder than large ones, the rate was (12.5-21.875) to $(5.88-10.5)$ for cylinder $7.62 \mathrm{~cm}$, and (0.26- 5.9) to (8.1-10.7) for cylinder $10.16 \mathrm{~cm}$, and (0.26-7.32) to (8.1-10.46) for cylinder $15.24 \mathrm{~cm}$. This mean that surface roughness have more effect on the water head under small size cylinders and this effect decays with increase in size of cylinder and rate of the flow. 

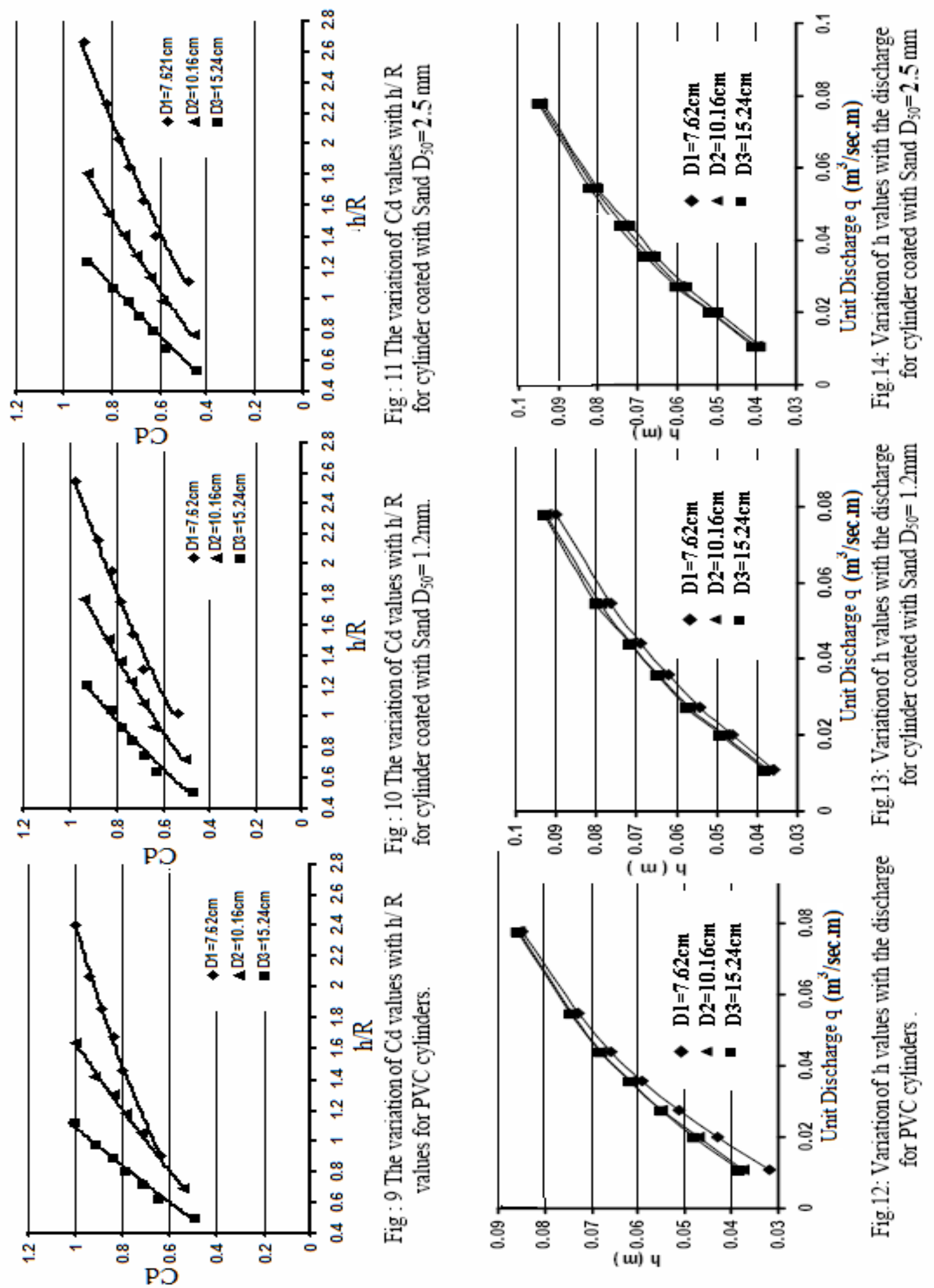
Othman: Effect of Size and Surface Roughness of Cylindrical Weirs on Over Flow ---.

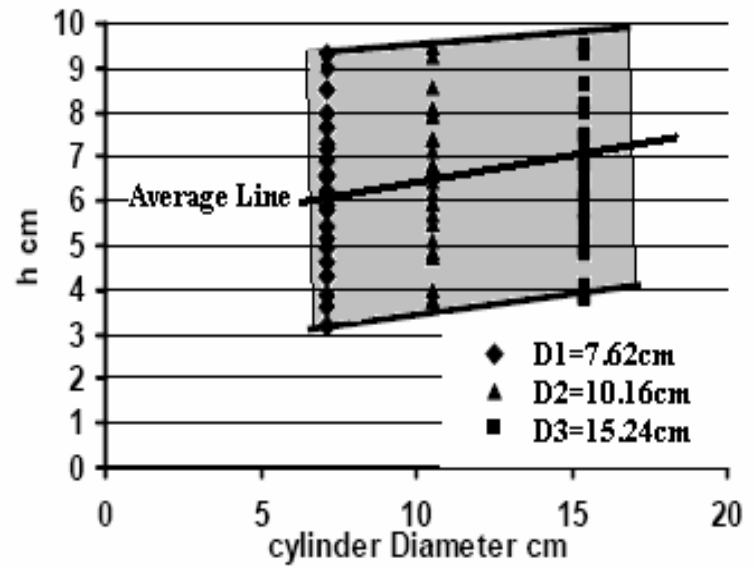

Fig.15: The Varation of $h$ Values for diferent flow rates of the flow with Cylinder diameter

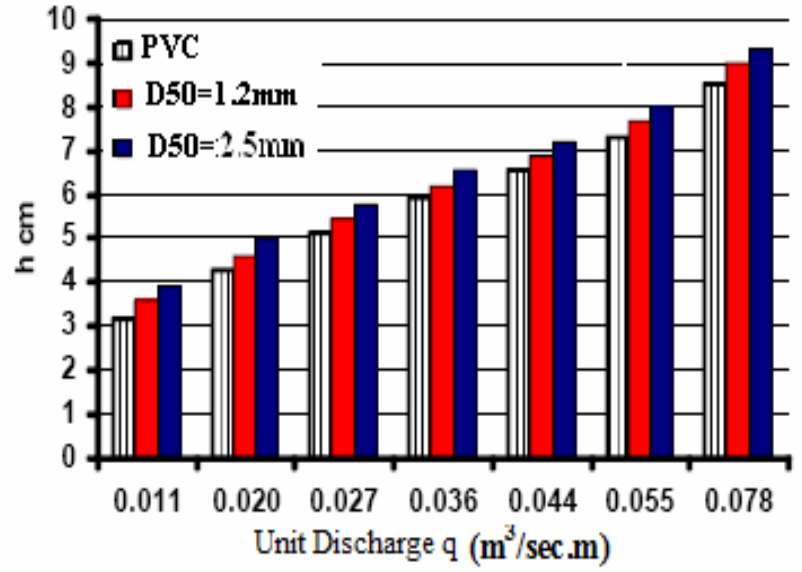

Fig.16: The varation of $h$ values for different flow rates at the diferent surface roughness for cylinder D1 $=7.62 \mathrm{~cm}$.

Table 4: The percentage of increase in $h$ values with the increase in cylinder roughness

\begin{tabular}{|c|c|c|c|c|c|c|}
\hline \multirow{2}{*}{$\begin{array}{l}\text { Cylinder } \\
\text { Size cm }\end{array}$} & \multirow{2}{*}{$\begin{array}{c}\text { q. } \\
\text { m }^{3} / \text { sec.m }\end{array}$} & \multirow{2}{*}{$\begin{array}{c}\text { smooth } \\
\text { PVC } \\
\text { h1 } \\
\text { cm }\end{array}$} & \multicolumn{2}{|c|}{$D_{50}=1.2 \mathrm{~mm}$} & \multicolumn{2}{|c|}{$D_{50}=2.5 \mathrm{~mm}$} \\
\hline & & & $\begin{array}{l}\text { h2 } \\
\text { cm }\end{array}$ & $\begin{array}{l}\text { (h2-h1) / } \\
\text { h1 } * 100 \%\end{array}$ & $\begin{array}{l}\text { h3 } \\
\text { cm }\end{array}$ & $\begin{array}{c}\text { (h3-h1) } \\
/ h 1 * 100 \%\end{array}$ \\
\hline \multirow{7}{*}{$\begin{array}{c}\text { Cylinder } \\
\text { D1=7.62cm }\end{array}$} & 0.011 & 3.200 & 3.600 & 12.500 & 3.900 & 21.875 \\
\hline & 0.020 & 4.305 & 4.624 & 7.399 & 4.966 & 15.345 \\
\hline & 0.027 & 5.140 & 5.445 & 5.925 & 5.780 & 12.442 \\
\hline & 0.036 & 5.929 & 6.209 & 4.713 & 6.546 & 10.408 \\
\hline & 0.044 & 6.577 & 6.902 & 4.954 & 7.194 & 9.396 \\
\hline & 0.055 & 7.300 & 7.650 & 4.795 & 8.000 & 9.589 \\
\hline & 0.078 & 8.500 & 9.000 & 5.882 & 9.400 & 10.588 \\
\hline \multirow{7}{*}{$\begin{array}{c}\text { Cylinder } \\
\text { D2=10.16cm }\end{array}$} & 0.011 & 3.776 & 3.780 & 0.265 & 4.000 & 5.940 \\
\hline & 0.020 & 4.721 & 4.850 & 2.741 & 5.117 & 8.393 \\
\hline & 0.027 & 5.495 & 5.689 & 3.514 & 5.957 & 8.393 \\
\hline & 0.036 & 6.166 & 6.457 & 4.713 & 6.714 & 8.893 \\
\hline & 0.044 & 6.808 & 7.145 & 4.954 & 7.379 & 8.393 \\
\hline & 0.055 & 7.413 & 7.900 & 6.568 & 8.072 & 8.893 \\
\hline & 0.078 & 8.550 & 9.250 & 8.187 & 9.470 & 10.760 \\
\hline \multirow{7}{*}{$\begin{array}{c}\text { Cylinder } \\
\text { D3=15.24cm }\end{array}$} & 0.011 & 3.820 & 3.830 & 0.262 & 4.100 & 7.330 \\
\hline & 0.020 & 4.800 & 4.900 & 2.083 & 5.188 & 8.083 \\
\hline & 0.027 & 5.510 & 5.750 & 4.356 & 6.039 & 9.610 \\
\hline & 0.036 & 6.170 & 6.500 & 5.348 & 6.820 & 10.535 \\
\hline & 0.044 & 6.810 & 7.178 & 5.403 & 7.516 & 10.370 \\
\hline & 0.055 & 7.460 & 7.998 & 7.216 & 8.200 & 9.920 \\
\hline & 0.078 & 8.600 & 9.300 & 8.140 & 9.500 & 10.465 \\
\hline
\end{tabular}




\section{Conclusions:}

Based on the analysis of experimental observations, the following conclusions are made:

1. There is an increase in Cd values with increasing in flow rate, an increase in discharge $618.2 \%$ leads to an increase in $\mathrm{Cd}$ value of $65.9 \%, 110.7 \%, 112 \%$ for diameters $7.62 \mathrm{~cm}, 10.16 \mathrm{~cm}$ and $15.24 \mathrm{~cm}$, respectively under smooth surface condition. While for cylinders coated by sand of $\mathrm{D}_{50}=1.2 \mathrm{~mm}$ the rate of the increase was $81.7 \%$, $85.4 \%, 87.58 \%$ and for cylinders coated by gravel $\mathrm{D}_{50}=2.5 \mathrm{~mm}$ the rate was $92 \%$, $97 \%, 103 \%$

2. There is an increasing in Cd values with decreasing in cylinder diameter under the same surface roughness. it is found that an increase in weir diameter from $7.62 \mathrm{~cm}$ to $10.16 \mathrm{~cm}$ ( $33 \%$ increase) make a reduction in Cd value about $5.3 \%$ While an increase in weir diameter from $7.62 \mathrm{~cm}$ to $15.24 \mathrm{~cm}$ (100\% increase) reduce $\mathrm{Cd}$ values around $6.6 \%$.

3. Cd values decreases with increasing surface roughness. Results shows that for the same cylinder under equal flow rate an increase in surface roughness of the weir from $\mathrm{D}_{50}=0 \mathrm{~mm}(\mathrm{PVC})$ to $\mathrm{D}_{50}=1.2 \mathrm{~mm}$ makes a reduction in $\mathrm{Cd}$ value around $6.5 \%$ ( as an average value), while an increase from $\mathrm{D}_{50}=0 \mathrm{~mm}$ to $2.5 \mathrm{~mm}$ makes a reduction about $13 \%$.

4. The effect of $\mathrm{h} / \mathrm{R}$ on $\mathrm{Cd}$ values will increase with increase in cylinder diameter.

5. For the same discharge the head of the water increases with increase in cylinder diameter. The result shows that an increase in cylinder diameter from $7.62 \mathrm{~cm}$ to $15.24 \mathrm{~cm}$ leads to increase $\mathrm{h}$ value around $15 \%$.

6. The effect of increase of surface roughness on $\mathrm{h}$ values will be more on small cylinders than large ones the rate was (12.5-21.875) to (5.88-10.5) for cylinder $7.62 \mathrm{~cm}$ and $(0.26-5.8)$ to $(8.1-10.7)$ for cylinder of diameter of $10.16 \mathrm{~cm}$ and $(0.26-$ $7.32)$ to $(8.1-10.46)$ for cylinder of diameter of $15.24 \mathrm{~cm}$.

\section{References:}

1. Chanson, H. and Montes, J.S., "Overflow Characteristics of Circular Weirs : Effect of Inflow Conditions", Journal of Irrigation and Drainage Engrg., ASCE, Vol.124,No. 3, pp. 152-162 (ISSN 0733-9437), 1998.

2. Bos, M. G., "Discharge measurement structures", 3rd Ed., International Institute for Land Reclamation and Improvement/ILRI, Wageningen, The Netherlands, 1989.

3. Kandaswamy, P. K., and Rouse, H., "Characteristics of flow over terminal weirs and sills", Journal of Hydraulic division, ASCE, Vol.83 No.4, pp, 1-13, 1957.

4. U.S. Bureau of Reclamation USBR. "Studies of crests for overfall dams", Boulder Canyon Project. Final Reports, Part VI Hydraulic Investigations, Bulletin 3, Denver, 1948.

5. Shesha Prakash and A. V. Shivapur, "Generalized Head-Discharge Equation for Flow over Sharp-Crested Inclined Inverted V-Notch Weir", Journal of Irrigation and Drainage Engineering, Vol. 130, No. 4, August 1, 2004. 
6. Ganapathy, K. T., Raj, A. N., and Ramanathan, V., "Discharge characteristics of oblique anicuts", The New Irrigation Era, Irrigation Branch, Public Works Department, Madras, India, 1964.

7. Mohapatra, P. K., "Coefficient of discharge for oblique terminal weirs", Journal. Inst. Eng. (I), pp. 227-233, 1964.

8. Muralidhar, D., "Some studies on weirs of finite crest width", Ph.D. thesis, Indian Institute of Science, Bangalore, India, 1965.

9. Sarginson, E.J., "The Influence of Surface Tension on Weir Flow", Journal of Hyd. Res., IAHR, Vol.10, No. 4, pp. 431-446., 1972.

10. Ramamurthy, A. S., Tim, U. S., and Rao, M. V. J., "Characteristics of square-edged round-nosed broad-crested weirs", Journal of Irrig. and Drain. Eng., ASCE, Vol. 114, No.1, pp. 61-73, 1988.

11. Ramamurthy, A. S., and Vo, N. D., "Characteristics of circular crested weir". Journal of Hydraulic. Eng., ASCE. Vol.119, No.9, PP. 1055-1062, 1993.

12. Keshava Murthy, K., and Shesha Prakash, M. N., "Practical constant-accuracy linear weir", Journal of Irrig. Drain. Eng., Vol. 120, No.3, pp.550-562, 1994.

13. Keshava Murthy, K., and Shesha Prakash, M. N., "On the dual head-discharge characteristics of a modified chimney weir", Journal of Hydraulic. Res., Vol. 31, No.4, pp. 502-516, 1996 b.

14. Keshava Murthy, K., and Shesha Prakash, M. N., "On the application of a new general algebraic optimisation technique to obtain the linear characteristics of a weir", ACTA Technica, Vol. 107, No. 3-4, pp. 265-275, 1996a.

15. Liu Chunrong, Huhe A. Ma Wenju, "Numerical and experimental investigation of flow over a semicircular weir", Acta Mechanica Sinica (English Series), The Chinese Society of Theoretical and Applied Mechanics Chinese Journal of Mechanics Press, Beijing, China. Vol.18, No.6, December 2002.

16. John k. Vennard and Robert L. Street, "Elementary Fluid Mechanics", Sixth Edition, John Wiley and Sons, 1982. 